\title{
Vitamin D receptor gene polymorphisms and osteoporosis
}

\author{
Johannes P.T.M. van Leeuwen, Andre G. Uitterlinden, Jan C. Birkenhäger, and \\ Huibert A.P. Pols* \\ Departments of Internal Medicine III and of *Epidemiology, Erasmus University Medical School, \\ Rotterdam, The Netherlands
}

Keywords: vitamin D receptor; osteoporosis; bone; genetics; polymorphism

\begin{abstract}
Osteoporosis is characterized by a decrease in bone mineral density (BMD) and microarchitectural deterioration of the bone structure leading to a higher susceptibility to fractures. ${ }^{1}$ The burden of fractures is substantial, both for the individual and public health care system. The most serious, i.e. hip fracture, is associated with a high mortality rate of approximately $25 \%$ within 1 year and a considerable decline of physical and social functions. Hip fracture is not a rare event, in that the lifetime risk of a hip fracture for a 50 year-old woman is on average about $16 \% .^{2}$ The total number of hip fractures in The Netherlands was 10,360 in 1987, and it is expected that, partly as a consequence of aging of the population, this number will exceed 20,000 by the year $2015^{3}$
\end{abstract}

Despite advances in therapy, reversal of bone loss in established osteoporosis remains problematic, and deformities and disability due to fractures often persist. Therefore, prevention of osteoporosis is a matter of priority. Identification of risk factors is of utmost importance for the development of programs for prevention of osteoporosis. Fracture risk is largely determined by BMD, which is the result of the peak value achieved in the third decade of life and subsequent age- and menopause-related bone loss. Lifestyle factors, i.e. diet, physical activity, smoking etc., are determinants of BMD and are of course targets for primary prevention. Three types of observations have shown that genetic factors are also important determinants of BMD. First are the differences in BMD between races; blacks have a higher BMD even when adjusted for body weight and height, and in addition a lower incidence of osteoporotic fractures. ${ }^{4}$ Second, twin studies have also demonstrated a

Address reprint requests to Dr. J.P.T.M. van Leeuwen, Department of Internal Medicine III, Erasmus University Medical School, Dr. Molewaterplein 40, 3015 GD Rotterdam, The Netherlands. genetic effect. In 1973, a study by Smith et al..$^{5}$ suggested an important genetic component in the determination of BMD. Later this was confirmed and extended by Pocock et al., who demonstrated that BMD showed a better correlation in monozygotic than in dizygotic twins. A subsequent longitudinal twin study has also demonstrated a genetic effect on the rate of change in BMD. ${ }^{7}$ In addition, the bone turnover markers type I procollagen and osteocalcin appeared to be under genetic influence. 8.9 Third, family studies have provided evidence for a genetic impact on BMD; daughters of mothers with osteoporosis have a lower BMD than daughters of women with a normal BMD. ${ }^{10-12}$ Altogether, it has been calculated that up to $75 \%$ of BMD is genetically determined, appearing as a polygenic, quantitative trait. These studies thus indicate the potential of genetic research to identify at an early stage individuals with an increased risk of developing osteoporosis.

The next, essential step in genetic research on osteoporosis is to dissect this polygenic trait into discrete genetic factors. Initially, the prime candidate genes are those coding for proteins playing a direct role in bone metabolism; it is also possible that further analysis of the human genome will reveal other important genes. At the moment, the only published data in relation to BMD and osteoporosis are for the vitamin D receptor (VDR) gene locus on chromosome 12 . The VDR is a member of the steroid hormone receptor family and induces gene expression via heterodimerization with the retinoic $X$ receptor and binding to a specific hormone response element. ${ }^{13}$ One of the genes strongly regulated by 1,25 -dihydroxyvitamin $\mathrm{D}_{3}$ is the bone-specific protein osteocalcin. ${ }^{14} 1,25$-Dihydroxyvitamin $\mathrm{D}_{3}$ is the biologically most active metabolite of vitamin $\mathrm{D}_{3}$ and is formed by two consecutive hydroxylation steps in the liver and the kidney. The seco-steroid hormone vitamin $\mathrm{D}_{3}$ is, together with parathyroid hormone, the major regulatory hormone for calcium and bone metabolism. 
In 1992 an association between a BsmI restriction fragment length polymorphism (RFLP) in intron 8 of the VDR gene and the serum osteocalcin concentration was demonstrated (Fig. 1). ${ }^{15}$ This RFLP appeared to be a better predictor of postmenopausal serum osteocalcin concentration than menopause. ${ }^{15}$ This was then extended to an analysis of the association between the BsmI RFLP and BMD. In 1994 Morrison et al. ${ }^{16}$ reported on the predictability of BMD on the basis of VDR alleles. They showed that in a Caucasian population the BMDs of dizygotic twins concordant for the BsmI RFLP were more similar to each other than discordant twins, illustrating the genetic contribution of this locus to the variability in BMD. This was substantiated by the analysis of the BMD of 311 healthy women, which showed that the "bb" genotype was associated with a higher BMD than the "BB" genotype. They calculated that the BB genotype reached the fracture threshold ( $=2$ S.D. below peak BMD) $8-10$ years earlier than the bb genotype. In view of the fact that the fracture incidence doubles every 4-5 years implies a 4-fold higher fracture risk for the BB genotype. Together these observations thus show a strong association between RFLPs at the VDR gene locus and BMD.

After the initial finding in this Australian population conflicting results have been reported on the association of the diallelic BsmI RFLP in the VDR gene and BMD. Some studies have confirmed the association between the BsmI polymorphism and BMD, even in women with different ethnic backgrounds ${ }^{17-20}$; other studies, however, could not demonstrate an association. ${ }^{21,22}$ There may be statistical as well as genetic explanations for this discrepancy, as follows. 1) The sample size, and consequently the statistical power, of the previous studies was limited. 2) There is bias, e.g. due to population admixture, in studies suggesting an association. 3) Linkage disequilibrium exists, e.g. the VDR gene locus itself is not causally related to BMD but is linked to a neighboring bone metabolism-related gene. As recombination between the marker locus (the VDR gene) and the putative bone metabolism-related gene may occur at each meiosis, linkage disequilibrium may be found in some populations but not in others. 4) There may be allelic heterogeneity, i.e. the VDR gene is the gene implicated in BMD, but different sequence variants of the gene are associated with BMD in different populations. The lack of association can then be explained by not testing for the allele associated with the VDR sequence variant in a particular population, and/or by using less informative genetic markers to test for an association.

At least in part these problems have been addressed by Uitterlinden et al. ${ }^{23}$ by the Rotterdam study, in a large ethnically homogeneous population-based sample. ${ }^{24}$ We ob-

VITAMIN D RECEPTOR GENE (12q13)

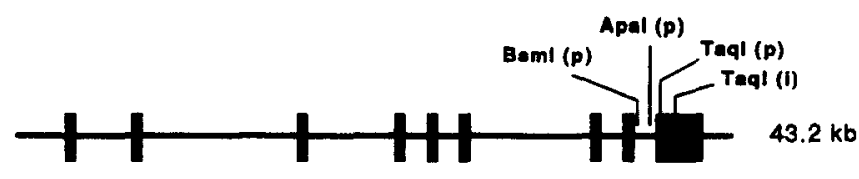

Figure 1 Depiction of the localization of the polymorphic (p) restriction sites for Bsml, Apal, and Taql. Note: in the last exon an invariant (i) Taql restriction site is present. served frequencies of the two alleles for the BsmI polymorphism almost identical to those in other studies of Caucasian populations. ${ }^{16,18-22}$ Despite the large population analyzed (798) only a weak association between the BsmI RFLP and BMD was observed in women, and none in men. The diallelic BsmI RFLP has a low genetic resolution in that it discriminates only two alleles reflecting three genotypes, which can thus diminish particular associations. To increase the genetic resolution we developed a direct haplotyping polymerase chain reaction test to monitor three clustered (BsmI, ApaI, and TaqI) RFLPs. As opposed to BsmI analysis, which detects three different genotypes, direct haplotyping can identify 12 different genotypes. In addition, instead of $5-6 \%$, differences in BMD between extreme genotypes now amounted to $18-25 \% .{ }^{23}$ These data show that probably part of the failure of several previous studies to detect an association could be attributed to sample size and to the use of a minimally informative diallelic RFLP. This is best illustrated by the fact that the "bAT-baT"' and "baT-baT"' genotypes have the second highest femoral neck BMD levels and the "bAT-bAT"' genotype the lowest BMD, despite the fact that all are homozygous "bb" (" $\mathrm{B}$," "A," "T," and " $b$," " $a$," " $t$ " denote the absence and presence of the BsmI, ApaI, and TaqI restriction sites, respectively).

Surprisingly, in the Rotterdam study, the association of particular VDR haplotype alleles with extreme BMD values is different from what was reported earlier, i.e. that the " $b$ " allele is associated with high and the " $\mathrm{B}$ " allele with low BMD levels. ${ }^{16-20}$ In contrast, we find the "BAt" haplotype allele (as one representative of the group with " $B$ "' alleles) to be associated with high BMD levels and the "bAT", haplotype allele (as one representative of the group with " $b$ ", alleles) with low levels. Our data thus suggest that there is allelic heterogeneity at the VDR locus among different populations. Alternatively, we cannot exclude that the VDR gene is in linkage disequilibrium with another bone metabolism-related gene and that recombination has occurred in our study population. In this respect, a more comprehensive analysis of sequence variation in functionally relevant parts of the VDR locus and in its chromosomal vicinity will assist in making this distinction.

One important consideration is that the polymorphisms used to explore associations between VDR alleles and BMD are anonymous polymorphisms, i.e. they do not code for different amino acids in the VDR protein. Therefore, a major question is how these allelic differences might relate to functional differences. In the initial study of Morrison et al. ${ }^{16}$ it was suggested that sequence variation in the $3^{\prime}$ untranslated region (UTR) of the VDR gene could be related to differences in expression of the gene. Sequencing of the 3.2-kilobase 3 '-UTR of two BsmI VDR genotypes, BB and $b b$, revealed differences at 13 sites. When these two 3 '-UTRs were inserted downstream of a murine mammary tumor virus long terminal repeat-driven luciferase reporter gene construct and transfected into COS-7 kidney cells and ROS17/2.8 osteoblast-like cells substantial differences in luciferase activity between the two UTRs were observed. In general, the 3 '-UTR of mRNAs has been suggested to be involved in determining mRNA stability and mRNA routing 
toward cellular locations where translation takes place. ${ }^{25,26}$ Sequence variations in this part of the mRNA may thus play an important role in defining subtle differences in expression levels and/or expression mechanisms between different alleles.

Indications that the VDR gene variations may have a functional impact have come from a recent study on 21 twins by the Australian group. ${ }^{27}$ In the BB genotype group (low BMD) baseline osteocalcin, 1,25-dihydroxyvitamin $\mathrm{D}_{3}$ $\left(1,25-(\mathrm{OH})_{2} \mathrm{D}_{3}\right)$, type I collagen, and inorganic phosphate levels were significantly higher. Treatment for 7 days with $2 \mu \mathrm{g}$ of oral $1,25-(\mathrm{OH})_{2} \mathrm{D}_{3}$ resulted in differences in responses, in that induction of osteocalcin synthesis and suppression of serum intact parathyroid hormone was more marked in the "bb" genotype, and stimulation of urinary calcium and hydroxyproline excretion in the "BB' genotype. In addition, a recent study has reported reduction in bone loss after calcium supplementation in a particular BsmI VDR genotype. ${ }^{28}$ However, these data are far from conclusive, and a detailed analysis of the functional consequences of the various VDR genotypes is needed. In this context it is pertinent to mention that little is known about the contribution of natural allelic variants in receptor genes to the diversity of response to hormones in normal physiology and in diseases.

In conclusion, polymorphisms at the vitamin $\mathrm{D}$ receptor locus on chromosome 12 are associated with BMD. Demonstration of this association is the first step in the genetic dissection of the complex trait of osteoporosis and in the development of an early predictor for the risk of osteoporosis. Functional analysis of polymorphisms is essential, and ultimately identification of other loci/genes associated with BMD, rate of bone loss, and fracture rate will be required for optimal prediction, prevention, and therapy.

\section{Acknowledgments}

We thank Q. Huang, C.J. Buurman, H. Burger, P.L.A. van Daele, C.M. van Duijn, A. Hofman, and the Dutch Preaventiefonds (Grant 002824890) for their support.

\section{References}

1. Consensus Development Conference (1993). Diagnosis, prophylaxis and treatment of osteoporosis. Am J Med 94:646-650.

2. Black DM, Cummings SR, Melton LJ (1992). Appendicular bone mineral and a woman's lifetime risk of hip fracture. J Bone Min Res 7:639-646.

3. Boereboom FTJ, de Groot RRM, Raymakers JA, Duursma SA (1991). The incidence of hip fractures in The Netherlands. Neth $J$ Med 38:51-58.

4. Melton LJ (1991). Differing patterns of osteoporosis across the world. In: Chesnut CH III (ed), New Dimensions in Osteoporosis in the 1990s, Excerpta Medica Asia, Hong Kong, pp. 13-18.

5. Smith DM, Nance WE, Kang KW, Christian JC, Johnston CC (1973). Genetic factors in determining bone mass. $J$ Clin Invest 52:2800-2808.

6. Pocock NA, Eisman JA, Hopper JL, Yeates MG, Sambrook PN, Eberl S (1987). Genetic determinants of bone mass in adults. J Clin Invest 80:706-710.

7. Kelly PJ, Nguyen T, Hopper J, Pocock N, Sambrook P, Eisman J (1993). Changes in axial bone density with age: a twin study. J Bone Min Res 8:11-18.
8. Kelly PJ, Hopper JL, Macaskill GT, Pocock NA, Sambrook PN, Eisman JA (1991). Genetic factors in bone turnover. J Clin Endo Metab 72:808-813.

9. Tokita A, Kelly PJ, Nguyen TV, Qi J-C, Morrison NA, Risteli L, Risteli J, Sambrook PN, Eisman JA (1994). Genetic influences on type I collagen synthesis and degradation: further evidence for genetic regulation of bone turnover. J Clin Endo Metab 78:1461-1466.

10. Evans RA, Marel GM, Lancaster EK, Kos S, Evans M, Wond SYP (1988). Bone mass is low in relatives of osteoporotic patients. Ann Int Med 109:870-873.

11. Seeman E, Hopper JL, Bach LA, Cooper ME, Parkinson E, McKay $\mathrm{J}$, Jerums G (1989). Reduced bone mass in daughters of women with osteoporosis. New Eng J Med 320:554-558.

12. Krall EA, Dawson-Hughes B (1993). Heritable and life-style determinants of bone mineral density. $J$ Bone Min Res 8:1-10.

13. Pike JW (1991). Vitamin $D_{3}$ receptor: structure and function in transcription. Ann Rev Nutr 11:189-216.

14. van Leeuwen JPTM, Birkenhäger JC, van den Bemd GJCM, Buurman CJ, Staal A, Bos MP, Pols HAP (1992). Evidence for the functional involvement of protein kinase $\mathrm{C}$ in the action of 1,25-dihydroxyvitamin $\mathrm{D}_{3}$ in bone. $J$ Biol Chem 267:12562-12569.

15. Morrison NA, Yeoman R, Kelly PJ, Eisman JA (1992). Contribution of transacting factor alleles to normal physiological variability: vitamin D receptor gene polymorphisms and circulating osteocalcin. Proc Natl Acad Sci USA 89:6665-6669.

16. Morrison NA, Cheng QI, Tokita A, Kelly PJ, Crofts L, Nguyen TV, Sambrook PN, Eisman JA (1994). Prediction of bone density from vitamin D receptor alleles. Nature 367:284-287.

17. Yamagata Z, Miyamura T, Iijima S, Asaka A, Sasaki M, Kazo J, Koizumi I (1994). Vitamin D receptor gene polymorphism and bone mineral density in healthy Japanese women. Lancet 344:1027.

18. Spector TD, Keen RW, Arden NK, Morrison NA, Major PJ, Nguyen TV, Kelly PJ, Baker JR, Sambrook PN, Lanchbury JS, Eisman JA (1995). Influence of vitamin D receptor genotype on bone density in postmenopausal women: a UK twin study. British Med J 310:13571360.

19. Fleet JC, Harris SS, Wood RJ, Dawson-Hughes B (1995). The Bsml vitamin $D$ receptor restriction fragment length polymorphism $(B B)$ predicts low bone density in premenopausal black and white women. J Bone Min Res 10:985-990.

20. Riggs BL, Nguyen TV, Melton LJ III, Morrison NA, O'Fallon WM, Kelly PJ, Egan KS, Sambrook PN, Muhs JM, Eisman JA (1995) The contribution of vitamin $\mathrm{D}$ receptor gene alleles to the determination of bone mineral density in normal and osteoporotic women. $J$ Bone Min Res 10:991-996.

21. Melhus H, Kindmark A, Amer S, Wilen B, Lindh E, Llunghall S (1994). Vitamin D receptor genotypes in osteoporosis. Lancet 344 949-950.

22. Hustmyer FG, Peacock M, Hui S, Johnston CC, Christian J (1994). Bone mineral density in relation to polymorphism at the vitamin D receptor gene locus. $J$ Clin Invest 94:2130-2134.

23. Uitterlinden AG, Pols HAP, van Daele PLA, van Duijn CM, Hofman A, Birkenhäger JC, van Leeuwen JPTM (1996). The association of vitamin D receptor gene polymorphisms with bone mineral density. $J$ Bone Min Res, in press.

24. Hofman A, Grobbee DE, de Jong PTVM, van den Ouweland FA (1991). Determinants of disease and disability in the elderly: the Rotterdam study. Eur J Epidemol 7:403-422.

25. St Johnston D (1993). The intracellular localization of messenger RNAs. Cell 81:161-170.

26. Bellman CA, Parker R (1995). Degradation of mRNA in eukaryotes. Cell 81:179-183.

27. Howard G, Nguyen T, Morrison N, Watanabe T, Sambrook P, Eisman J, Kelly PJ (1995). Genetic influences on bone density: physiological correlates of vitamin $\mathrm{D}$ receptor gene alleles in premenopausal women. $J$ Clin Endo Metab 80:2800-2805.

28. Krall EA, Parry P, Lichter JB, Dawson-Hughes B (1995). Vitamin $D$ receptor alleles and rates of bone loss influences of years since menopause and calcium intake. J Bone Min Res 10:978-984. 